\title{
TEACHING BUSINESS ENGLISH FOR ACADEMIC PURPOSES
}

\author{
Carina Brânzilă \\ Al. I. Cuza University of Iași, Romania \\ carinabranzila@gmail.com
}

\begin{abstract}
Research and experience have long indicated that the acquisition of the mother tongue is different from the acquisition of a non-native language. Also, the efforts and the cognitive impact of language learning are different in childhood compared to adulthood, whereas young people and adults differ in the way they learn and should be taught a foreign language. Learning a new language at the level of a native speaker is a dream all students share, but it may well be impossible and also irrelevant in the context of the ever-changing landscape of a living language. Furthermore, it is common knowledge that the acquisition of a foreign language due to natural exposure or immersion offers better results than its acquisition in a formal learning environment. To complicate matters even further, studies show that acquiring a second language is usually much more difficult than acquiring a third language, for example. Despite all these though, the job of a language teacher, especially of adult students, needs to serve its purpose as well as possible. This article will look into some of the modern trends of teaching not just a foreign language (English), but a specialized one (Business English) to undergraduates in the context of a Romanian university. How can a teacher better accomplish this task? How useful can Business English prove to be to students taking it as a compulsory subject, not by choice? Are there methods to improve its acquisition, especially in the context of the current pandemic? The article will take a closer look at all these, with practical examples of good practices.
\end{abstract}

Keywords: Business English, teaching, foreign language acquisition

JEL Classification: $A 1 ; A 2 ; A 3 ; Y 8$

\section{Historical background of English as a second/foreign language}

The history of teaching English as a foreign language spawned from the needs of multilingual societies, where people of various origins had to communicate in order to live. It is as old as Colonialism, when church people would try to instill a sense of religion together with language knowledge in the new-found people of mysterious lands. The more organized form of teaching a language per se appeared much later though, some authors like Cavanaugh claiming it was 'a truly American educational situation' that 'grappled with the problem of how to teach those who do not speak the common language' and 'wrestled with the question of what the common language should be' as 'the problem of a multilingual society is, of course, inherent in the problems of a multinational society'. (Cavanaugh, 1996)

The online dictionary of teaching English as a second language claims, along the same line, that the teaching of English as a lingua franca of business communication began as long ago as the $15^{\text {th }}$ century, when the British trade routes were becoming larger and larger. However, the proper education in English began much later, just as in the case of the 'American situation'. The purpose of this initial spread of English was to help the growth of the Empire 'by passing a British world view down to the lower classes through legislation and local influence' while at the same time educating the 'upper-class colonists and local government officials, indoctrinating them with British ideas and culture, including the English language' (ESL dictionary, 2021). This is the main reason of English being the most learned language across the world for a very long time and perhaps the most studied by authors of second language acquisition. 
The indigenous people in various territories across the world could not be taught in their entirety the new language of English, nor their language be forgotten completely, so a bilingual system was put in place. This was also helpful for the governance of the new lands as it brought the support of the population 'while holding to the beliefs and practices of the British' in the case of those in charge (Merriam-Webster, 2021). As David Crystal notes, 'a language has traditionally become an international language for one chief reason: the power of its people - especially their political and military power [...] The history of a global language can be traced through the successful expeditions of its soldier/sailor speakers. And English has been no exception' (Crystal, 1997). However, it was the economic growth which ensured that one language, particularly English in this case, would hold its place as a lingua franca. The advent of technology ensured easier ways of communication and the media spread to extents never encountered before and these two factors combined to ensure the world domination of English. 'British political imperialism had sent English around the globe, during the nineteenth century, so that it was a language 'on which the sun never sets'. During the twentieth century, this world presence was maintained and promoted almost single-handedly through the economic supremacy of the new American superpower. Economics replaced politics as the chief driving force.' (Crystal, 1997).

Although English is not an official language in too many countries outside the Commonwealth and the United States, it remains the most studied secondary language in the world.

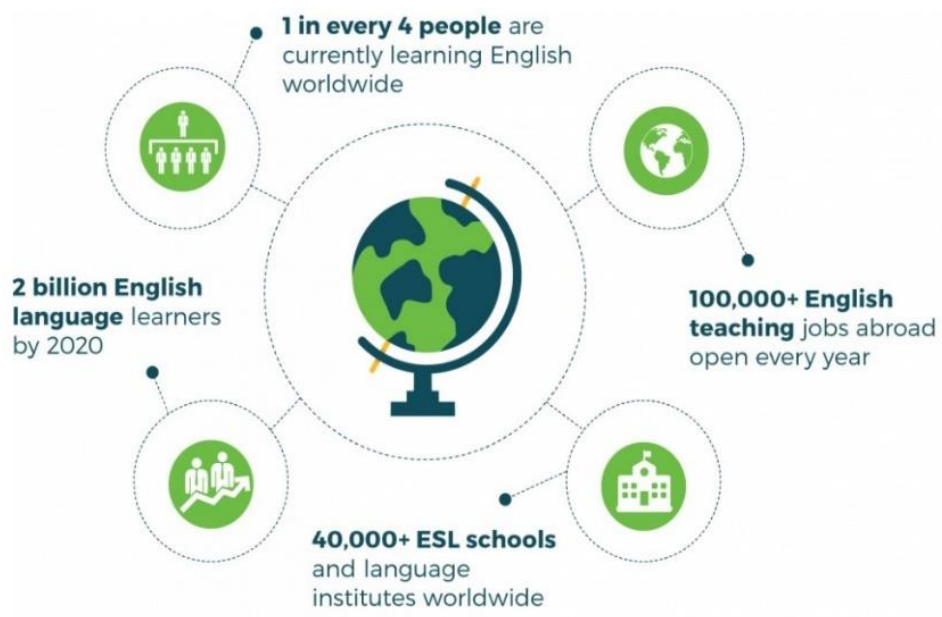

Source: Studies by the British Council (2016) and Pearson Learning/CSV Advisors (2013)

Figure 1: The popularity of ESL across the globe

Some linguists believe that it is no longer the exclusive cultural sign of native English speakers, but rather a language that absorbs aspects of cultures around the world as its influence expands. This has a two-sided effect: that of a continuous enrichment of the English lexicon with the addition of innumerable words from foreign cultures, but at the same time a bad influence on the existence and use of local languages, some of which being brought to the brink of extinction. For example, by exercising its domination over Wales, Scotland and Ireland, England imposed, in the past centuries, English as the main language while Welsh, Scottish and Irish were excluded from schools and administration. It was not until the 20th century that the United Kingdom government initiated a reanalysis of the 
problem, stimulating the reaffirmation of these ancestral languages of the islanders and even granting them the status of a second official language, after English. However, few people still speak these languages and its users are of old age, whereas the interest in their existence has greatly diminished. If these will survive or not, only time will tell. As David Crystal observes, 'the arrival of English as a global language could directly influence the future of these or many other minority languages. An effect is likely only in those areas where English has itself come to be the dominant first language, such as in North America, Australia and the Celtic parts of the British Isles. The early history of language contact in these areas was indeed one of conquest and assimilation, and the effects on indigenous languages were disastrous'. (Crystal, 1997)

\section{Context of teaching English as a second language}

However, English as a language has developed immensely over time by assimilating influences. The lexicon of the language has words borrowed from over 300 languages and much if it is of Classical and Romance origin. The high degree of development of English has to do with it being alive, quite possibly one of the most dynamic and open to change language, particularly due to the fact that it is so widely used on the globe and in so many international contexts, benefitting from such a large input from other languages and cultures it co-exists with. Tom McArthur, the reputed Oxford linguist regards with circumspection the current status of English, with its variants, traditional and 'innumerable varieties' ranging from high to low registers, raising an important question: 'What does a lingua franca mean...with regard to English? [...] The answer...had to be Standard English... but whose Standard English and what in any case constitutes the standard for a language whose users are counted in hundreds of millions worldwide?' (McArthur, 2001). He also claims that the ESL teaching would benefit from a single supranational standard language, offering the examples of Australia's and Canada's efforts to create an endonormative standard combining elements of the two longest existing exonormative standards of British and American English.

David Graddol also comments for a British Council research study that English has been affected by patterns of trade and more recently by work habits - including, it must be said, the last year's shift towards extensive online teaching. The author talks about the second language speakers being 'drawn towards the inner circle of first language speakers and foreign language speakers to the outer circle of second language speakers' (Graddol, 2006), this migration changing the needs regarding English as the language itself is changing and diversifying. There is a widespread belief among specialists that more and more people are becoming bilingual, especially since the age of learning a new language has dropped to oneyear olds being taught English by private educators. In fact, with the world's population fluently speaking more than one language on a constant basis, the future of English may be ambiguous to a certain extent, as it may, at some point, become a second language worldwide, rather than the dominating lingua franca. These days, in truth, many companies consider English as a pre-requisite when recruiting: it goes without saying that future employees already speak English and the need of a second (or third, in fact) language emerges. Children have foreign baby-sitters who talk to them in English at all times, families are mixed and if not, they travel more than it used to happen in the past, most kindergartens offer classes of English from the start, state schools have included it in their curricula everywhere in the world and there is an abundance of private and language schools that teach children intensive English from an early age. There is also the question of the technologized global world we live in today and the youth being exposed to electronic devices from their first year of existence: their parents' smart-phones or tablets, computers and laptops, console and video games. Children today are tech-savvy and extensive techusers, with English being a main tool for technology. For example, children spend hours playing computer games networking with children of similar age and interests across the 
globe and the new lingua franca of their interaction is obviously English. If for example in the post-revolution years, Romanian children got exposed to cartoon channels that were mainly in English, thus learning it from their favourite characters, the Romanian children of today learn the language from the websites they visit, from the menus of their devices, from youtube or their video games. Their level will of course vary, there might be issues with their knowledge, but an increasingly number of students nowadays present this pattern. Specialist literature worldwide is struggling to analyze this phenomenon and its possible outcomes, psychologists, educators and parents are concerned with this fact, especially since the virus crisis of the last year has moved everything online - including face-to-face schools and courses. There are numerous opinions and studies, most of them raising the alarm, particularly from the point of view of children's healthy developments, but the situation is what it is and there is no turning back from it.

\section{English for specific purposes}

Discussing the characteristics of ESP since its advent in the world of English learning, Hyland states that 'ESP has consistently been at the front line of both theory development and innovative practice in teaching English as second/other language. Assisted by a healthy receptiveness to the understandings of different perspectives, ESP has consistently provided grounded insights into the structures and meanings of texts, the demands placed by academic or workplace contexts on communicative behaviours, and the pedagogic practices by which these behaviours can be developed. ESP is, in essence, research-based language education and the applied nature of the field has been its strength, tempering a possible overindulgence in theory with a practical utility. The success of this marriage of theory and practice has, I believe, been achieved because of clear emphasis on the idea of specificity, a concept fundamental to most definitions of ESP' (Hyland, 2002). The author pleads for a need of in-depth research in the field, as this will help educators be more prepared for their students and cover the linguistic aspects of ESP: 'its heavy dependence on a strong research orientation... highlights the importance of target behaviours ...which, in turn, has influenced the kinds of data we collect, the ways we collect it, and the theories we use to understand it.' (Hyland, 2002)

Authors like Swales defines ESP as part of the larger field of Language for Specific Purposes (LSP), more precisely: "the area of inquiry and practice in the development of language programs for people who need a language to meet a predictable range of communicative needs." (Swalws, 1992), whereas Dudley-Evans and John describe ESP following a threelevel model: its purpose is to meet the student's needs only, so it is very specific, it only uses core methodology and activities adapted to the purpose, it focuses on specific activities designed to teach grammar, lexis, register, study skills, discourse and genre suitable to the needs of the learners. Apart from these fundamental values, there are other five more flexible characteristics of ESP: its direct relation and influence on specific disciplines, the use of a differentiated and specific methodology than that of General English courses, its usefulness mostly to adult learners, either university students, in-company learners or people opting for a specific language institute and sometimes for high-school students in a specific context, ESP may be leveled from beginners to proficient learners but it is mostly taught to intermediate students onwards, as the majority of ESP courses imply some previous language skills (Dudley-Evans, John, \& Jo, 1998). Being practically-orientated, DudleyEvans and St John description of ESP is that of a distinctive methodological approach which highlights the more specific learner needs and a set of teaching patterns that take into account the fact that students often have in-depth knowledge in the field; hence the need for the instructor to be well-prepared, to undergo research on the matter prior to classes and to make sure all lessons are well-prepared in advance. Obviously, there is no need, nor real possibility to match the students' level of expertise, particularly if they are top-ranking executives or people with large experience of the field. However, courses need to be 
updated and relevant on all occasions, as another characteristic of ESP courses, particularly English for business, is their applicability on the job market in real time. Usually people taking up Business English courses are people who need it, rare are the cases of people studying for it for themselves, as it may occur with General English.

Hutchinson and Waters discuss the advent of ESP as a response to certain emerging trends in the world of languages: firstly, the world advances in science, technology and economy that required more language knowledge to deal with these changes; secondly the revolution in linguistigs, 'the greatest expansion of research into the nature of particular varieties of English'; thirdly and most importantly a focus on the learners of the language 'seen to have different needs and interests, which would have an important influence on their motivation to learn and therefore on the effectiveness of their learning', which introduced real-life materials into the classroom and brought a focus on the needs of the students themselves, be it technology or commerce. This new teaching approach meant highly relevant courses for highly motived students. 'All three factors seemed to point towards the need for increased specialization in language learning.' (Hutchinson \& Waters, 1987)

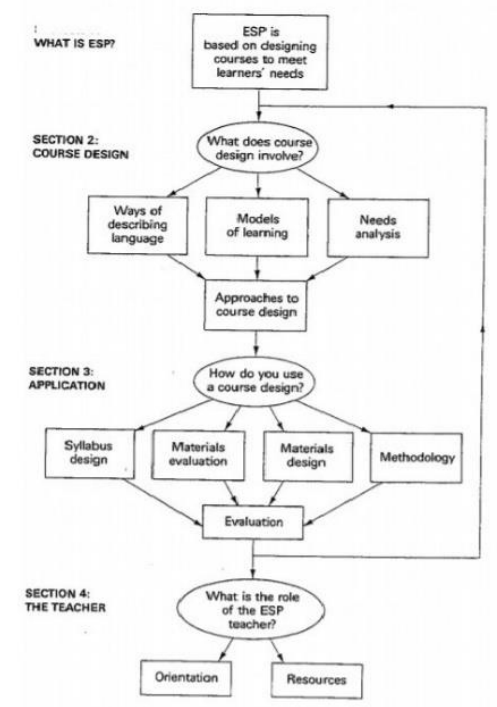

Figure 2. Hutchinson and Water's outline of a learning-centered approach to ESP (Hutchinson \& Waters, 1987)

\section{Business English}

Business English is part of the wider category of English as a second language (ESL) or English as a foreign language (EFL), but it is also considered an ESP (for special purposes) type. Considering the above described expansion of the language itself and its important characteristic as being the world of trade, commerce and communication, it is only normal that Business English has gained such a high profile. If English was a global market Business English would be its main currency. The term Business English is encompassing and includes all language items implied by business activities, spoken or written: business related vocabulary, important business communication skills like presentations, negotiations, meetings; contract-drafting, business letters, emails or report writing. It has a very specific character and very typical needs: for example, verbal communication (speaking skill) is of paramount importance, as most business is being done this way and less in writing. Grammar is obviously being studied, too, but always in close connection with a specific vocabulary and with a practical outcome, not per se as it might happen in a linguistic course, 
for example. The main characteristic of Business English, especially taught in-company, is its practicality and applicability. People learning Business English do that for a practical and often immediate reason.

Business English appeared somewhat later in the field of research and then in teaching practice, as the main interest of ESP was on its Academic field and perhaps the Technological one. Bargiela-Chiappini and Zhang even claim that 'it was not until the 1990a that discourse analyses, contrastive ethnography, laid the foundation of a multimethod approach to business discourse [...] literature on business communication considerably enlarged the original, narrow view of Business English as the teaching of the language for vocational purposes through linking linguistic performance with actual business activities' (Bargiela, Chiappini \& Zhang, 2013).

There are also authors who claim there are important differences between English for Academic Purposes (EAP) and English for Business Purposes (BE), as the first deals with generic skills or language that may be useful across a range of disciplines or purposes, whereas the second is more customer-oriented and more practical in its approach, sometimes up to the point of establishing the content or curriculum with the input from students. BE resides more in the area of ESP, argues for instance Ken Hyland, claiming tis is 'largely due to ESP's distinctive approach to language teaching based on identification of the specific language features, discourse practices and communicative skills of target groups, and on teaching practices that recognize the particular subject-matter needs and expertise of learners' (Hyland, 2002).

However, the focus of the ESL world on Business English legitimizes its existence, it has been in high demands for decades now, never stopping, merely adapting to the needs of the learners and to the realities of the world around. The interest of the job-experienced learner is constantly taken into consideration by teachers, language schools and book publishers, who all adjust to the interest and needs of the learners in order to create content to respond to their demands. This is starting to show now, in times of pandemic, by the adaptation of teaching materials and format of courses to best suit the changes brought by the online medium.

Ruth Spack argued as early as 1998 the legitimacy of language teachers dealing with English for specific purposes, as they might lack the expertise and confidence to teach subject specific conventions, which might be better suited for subject specialists themselves. However, the specialists might be focused on research or their own field of expertise and might lack the methodology to do so, or simply have no interest in sharing their knowledge by teaching it to others. Another of Spack's much debated points was that English for specific purposes such as Business English might be too difficult for some students with lower levels of English; this might indeed be true, especially in the case of undergraduates of a university when students do not get to choose what subjects they have to study, like in the case of many Romanian universities; however this is not the case of adults taking up English for Business on their employer's request, as they might be highly motivated precisely because of this reason. Spack also claims there are generic skills and forms of language that are the same across a range of disciplines, professions, or purposes. This is true to a certain extent, as Business English for instance does have a highly specialized vocabulary, as well as very specific needs: language for presentations, for meetings and for negotiations (Hutchinson and Waters, 1987).

In Romania, Business English is taught to undergraduates in universities, as well as to Master's students in certain specializations, as part of their Business studies programme, for example in a BA, or at a faculty of economics. We are thus dealing with ESP as well as EAP at the same time. The content is adapted to the students' main needs, but less than in a language school, for instance. There is no opportunity for initial testing, nor for individualized feedback at all times, as the numbers of students are rather large. Also, there is no negotiated curriculum, nor immediate response to students' requirements - as with any 
state institution, change takes time. However, the teaching materials are suitable and reflect the international market changes. Teachers work hard to offer students a real-life environment that reflects the business environment, although the classroom space and time does not always allow for role-play, for work in pairs or small groups or for a very interactive lesson. The pandemic meant more online teaching, obviously, and this allows for even less flexibility, but at the same time teaching becomes more technologized and students are happier this way. Be it face-to-face or online, the Business English teacher needs to take into account relevant topics such as real-life texts in reading, letters of intentions and resumes in writing, the business vocabulary, or topics like advertising or management, to give some examples. It is not an easy job and preparation time may be quite long, but at the same time, a BE university course needs to reflect the real world and respond to the needs of the market, as its main purpose is to prepare students for their future jobs.

The future of Business English looks bright; it is however important to take into account the role of Business English in the development of students and in the context of their studies. It is evident that many institutions offer special courses to young people in order to improve their abilities. However, more active actions and sophisticated multidisciplinary approaches towards Business English and English for Specific Purposes will encourage the researchers to get closer and to share their investigation with the community interested in the same field that will definitely lead to the new openings. Globalization will continue to fuel new demands and promote new visions not only towards of Business English but of the language itself. Teaching Business English in the challenging environment of today means being open to the changes on the job market and integrating technology into teaching, even beyond the restrictions of the pandemic. Teachers need to be flexible so as to adapt to newness successfully and be prepared for the next waves of change.

Or, as Dana Poklepovic writes for the blog of BESIG (Business English Special Interest Group of the International Association of Teachers of English as a Foreign Language): 'Teaching language structures is not enough to help learners interact effectively. To overcome this challenge, we'll need to integrate interpersonal and soft skills into the BE syllabus: for example, how to build trust, to be assertive, to give feedback, making effective questions, building relationships... Starting from a higher-level language level base, we may see an increase in the demand for short, more specific courses; e.g. English for Accountants, Legal English... This technological progress will impact on how we deliver our classes. Whether we teach face-to-face or online, learners will demand flexible learning formats. We can offer flexibility, for example, by including mobile-learning apps that allow students to access material, practice speaking, listening and also to share their files and videos with the group... Teaching intercultural aspects will be commonplace. In terms of language teaching, the focus will be on developing fluency and listening skills as well as working on quick response time' (Poklepovic, 2018).

All these are actual, updated teaching trends that need to be taken into account by language instructors, be it in an academic teaching context or elsewhere, because it is obvious that Business English will continue to flourish as long as there will still be a business world to put it to good use.

\section{References}

Figure 1: The popularity of ESL across the globe, retrieved from https://www.teachaway.com/blog/whyyou-should-get-tefl-certified-with-teach-away-to-teach-english-online which retrieved and adapted it from the British Council and Pearson websites. Accessed 6 May 2021

Figure 2: Hutchinson and Water's outline of a learning-centered approach to ESP, retrieved from Hutchinson, T., \& Waters, A. English for specific purposes. Cambridge: Cambridge University Press. 1996. pp. 7

Bargiela, Chiappini, F., \& Zhang, Z. Business English. In B. \&. Paltridge, The Handbook of English for Specific Purposes. John Wiley \& Sons, 2013, pp. 36-37 
Crystal, D., English as a second language. Cambridge university press, 1997, pp. 11-42. http://culturaldiplomacy.org/academy/pdf/research/books/nation_branding/English_As_A_Global_Lan guage_-_David_Crystal.pdf. Accessed 8 May 2021

Cavanaugh, M. P., History of Teaching English as a Second Language. The English Journal, vol. 85, no. 8, 1996, pp. 40-44. JSTOR, www.jstor.org/stable/820039. Accessed 6 May 2021.

"ESL teaching". ESL dictionary. https://esl.yourdictionary.com/about-esl/the-history-of-esl.html. Accessed 7 May 2021.

Hyland, K. Activity and evaluation: Reporting practices in academic writing. In J. Flowerdew (Ed.), Academic discourse, Longman, 2002, pp. 115-130.

Graddol, D. English Next. The British Council. London, UK. 2006. http://www.britishcouncil.org/learning-research-english-next.pdf. Accessed 6 May 2021

Hutchinson, T., \& Waters, A. English for specific purposes. Cambridge: Cambridge University Press. 1996. pp. 7-8

"language" Merriam-Webster.com. Merriam-Webster, 2021. Accessed 6 May 2021.

McArthur, T., World English and World Englishes: Trends, Tensions, Varieties, and Standards. Language Teaching, vol. 34, no. 1, 2001, pp. 1-20., doi:10.1017/S0261444800016062

Pockepovic, D., Into the future of business English. BESIG blog. https://besig.iatefl.org/futurebusiness-english/. Accessed 6 May 2021

Spack, R., The Acquisition of Academic Literacy in a Second Language: A Longitudinal Case Study. Written Communication, vol. 14, no. 1, Jan. 1997, pp. 3-62

Swalws, J., Language for Specific Purposes. In W. Bright, International Encyclopedia of Linguistics, Oxford University Press 1992, pp. 300-301. 